\title{
Ostra białaczka z koekspresją antygenów limfo- i mieloidalnych oraz masywną limfadenopatią jako problem diagnostyczny i terapeutyczny
}

\author{
Acute leukemia with coexpression of lymph and myeloid antigens \\ and massive lymphadenopathy as a diagnostic and therapeutic problem
}

\author{
Marcin Fejklowicz ${ }^{1}$, Sebastian Grosicki ${ }^{2}$ \\ ${ }^{1}$ Oddział Hematologiczny, Zespół Szpitali Miejskich w Chorzowie \\ ${ }^{2}$ Zakład Profilaktyki Chorób Nowotworowych, Wydział Zdrowia Publicznego, \\ Śląski Uniwersytet Medyczny w Katowicach, Bytom
}

\begin{abstract}
Streszczenie
W pracy opisano przypadek 20-letniego chorego na ostra biataczke o nieustalonym pochodzeniu liniowym z towarzyszaca masywna limfadenopatia. U pacjenta zastosowano leczenie jak $w$ ostrej biataczce limfoblastycznej, wedtug protokotu PALG ALL6, uzyskujac catkowita remisje hematologicznq oraz metabolicznq choroby podstawowej.
\end{abstract}

Słowa kluczowe: ostra białaczka, limfadenopatia, chemioterapia, remisja hematologiczna, remisja metaboliczna

Hematologia 2018; 9, 2: 146-152

\begin{abstract}
The paper describes the case of a 20-year-old patient with acute leukemia of undetermined linear origin accompanied by massive lymphadenopathy. The patient was treated with acute lymphoblastic leukemia regimen, according to the PALG ALL6 protocol, achieving complete hematological and metabolic remission of the underlying disease.
\end{abstract}

Key words: acute leukemia, lymphadenopathy, chemotherapy, hematological remission, metabolic remission

Hematologia 2018; 9, 2: 146-152

\section{Wprowadzenie}

Ostra białaczka o nieokreślonym pochodzeniu liniowym to podtyp ostrej białaczki, w której cechy morfologiczne i immunofenotypowe blastów nie pozwalają na ich jednoznaczne zaklasyfikowanie do grupy białaczek limfo- czy mieloblastycznych. U dorosłych pacjentów takie białaczki charakteryzują się najczęściej opornością na leczenie, którą częściowo przypisuje się wysokiemu odsetkowi chorych $z$ niekorzystnymi aberracjami cytogenetycznymi. Nie prowadzono dotąd prospektywnych, kontrolowanych prób klinicznych służących ustaleniu optymalnego sposobu leczenia. Ograniczone dane sugerują, że korzystniejsze jest leczenie według schematów zalecanych w leczeniu chorych na ostrą białaczkę limfoblastyczną $z$ następowym przeszczepieniem allogenicznych krwiotwórczych

Adres do korespondencji: Marcin Fejklowicz, Oddział Hematologiczny, Zespół Szpitali Miejskich w Chorzowie, ul. Strzelców Bytomskich 11, 41-500 Chorzów, e-mail: doc_f@o2.pl 
komórek macierzystych (allo-HSCT, allogeneic hematopoietic stem cell transplantation) [1]. W pracy zaprezentowano opis przypadku 19-letniego chorego na nietypową ostrą białaczkę $z$ obecnością komórek o dużym stopniu niedojrzałości z ekspresją antygenów CD34, CD38, HLA-DR oraz koekspresją antygenów charakterystycznych dla linii limfoidalnej CD7 i mieloidalnej CD117.

\section{Opis przypadku}

W lipcu 2016 roku do kliniki radioterapii i chemioterapii przyjęto 19-letniego chorego, dotąd nie leczącego się przewlekle, $z$ powodu rozpoznanego na podstawie badania histopatologicznego węzła chłonnego chłoniaka nie-Hodgkina $z$ komórek T. Chory w styczniu 2016 roku wyczuł guz w lewym dole pachowym, który stopniowo się powiększał. Gwałtowna progresja nastąpiła w maju 2016 roku - chory zaobserwował szybkie powiększenie się guza, a także pojawienie się nowej zmiany guzowatej po lewej stronie szyi. Towarzyszyły temu objawy ogólne pod postacią gorączki, osłabienia, zmniejszenia tolerancji wysiłku oraz utraty około $8 \mathrm{~kg}$ masy ciała w czasie 2 miesięcy. $Z$ tych powodów 7 czerwca 2017 roku pacjent zgłosił się do lekarza, skąd został skierowany na pobranie węzła chłonnego do badania histopatologicznego. 1 lipca 2017 roku, po wykonaniu badań immunohistochemicznych, uzyskano następujący wynik: choroba limfoproliferacyjna $z$ komórek wykazujących ekspresję markerów limfocytów T. Ustalenie jednoznacznego rozpoznania uniemożliwiał brak korelacji obrazu histologicznego (ryc. 1) mogącego odpowiadać nietypowemu chłoniakowi anaplastycznemu $\mathrm{z}$ fenotypem komórek guza: ALK (anaplastic lymphoma kinase)(-), BCL6 (+/-), CD1a(-), CD2(2+/-), CD3(-), CD4(++/-), CD5(-), CD(8-), CD10(-), CD20(-), CD30(+/-), CD43(+), CD79a(-), CD7(+), CK1/3(-), MUM1(-), MPO(-), Ki-67 60\% oraz młody wiek pacjenta. Ze względu na trójliniową cytopenię (liczba krwinek białych [WBC, white blood count] 1,11 G/1, stężenie hemoglobiny [Hb] 7,3 g/dl, liczba płytek krwi [PLT, platelets] $55 \mathrm{G} / 1$, liczba krwinek czerwonych [RBC, red blood count] 2,31 T/1), wykonano badanie immunofenotypowe szpiku, stwierdzając 88-procentowy naciek komórkami blastycznymi o fenotypie CD34 ${ }^{\text {high }}(+)$, CD19(-), CD3(-), CD5(-), CD2(-), CD25(+), CD43(+), CD1a(+), CD7(+) o ekspresji od niskiej do nieco wyższej niż w prawidłowych limfocytach T, CD30weak (ok. 40\% komórek z silniejszą koekspresją CD7), CD64(-), CD13(-), CD33(-), CD117(+) (ok. 66\% komórek z silną

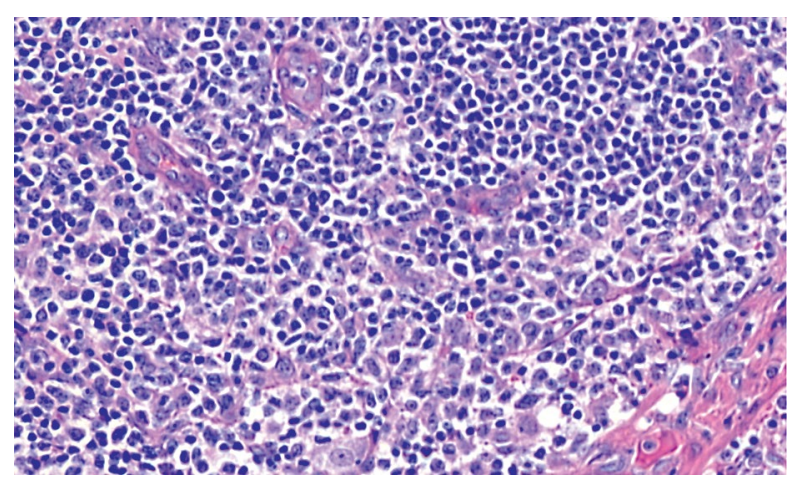

Rycina 1. Obraz histopatologiczny węzła chłonnego pacjenta (barwienie hematoksyliną-eozyną, powiększenie $\times 40$ )

Figure 1. Histopathological picture of the patient's lymph node (hematoxylin-eosin staining, $\times 40$ )

koekspresją HLA-DR), MPO(+) $(4,8 \%)$, TdT $(+)$ (36\% komórek, przy CD7low), cyCD3(-), CD38(+). Diagnostykę uzupełniono o badanie tomografii komputerowej (CT, computed tomography) głowy, nie uwidaczniając patologii w obrębie ośrodkowego układu nerwowego, oraz badanie metodą pozytonowej tomografii emisyjnej/tomografii komputerowej (PET/CT, positon emission tomography/computer tomography), w którym opisano masywnąuogólnioną limfadenopatię, szczególnie w okolicy szyi, gdzie węzły tworzyły konglomeraty o wymiarach $25 \times 50 \times 65 \mathrm{~mm}$ po prawej stronie, $120 \times 70 \mathrm{~mm}$ po lewej stronie oraz $150 \times$ $85 \times 90 \mathrm{~mm}$ w okolicy lewej pachy, z maksymalną standardową wartością wychwytu glukozy (SUVmax, maximum standard uptake value) równą 10,6 (ryc. 2), oraz powiększenie śledziony do wymiarów $160 \times 74$ $\times 225 \mathrm{~mm}$.

W celu dalszego leczenia chorego skierowano na oddział hematologiczny szpitala miejskiego. Przy przyjęciu pacjent był w dość dobrym stanie ogólnym. Utrzymywały się gorączka i osłabienie. W badaniu przedmiotowym zwracały uwagę olbrzymie masy węzłowe w lewym nadobojczu i dole pachowym (ryc. 3). W badaniach laboratoryjnych stwierdzono pancytopenię, WBC 1,5 G/l, liczbę neutrofilów 0,44 G/l, stężenie $\mathrm{Hb} 9,4 \mathrm{~g} / \mathrm{dl}, \mathrm{RBC}$ 2,93 T/1, liczbę PLT $91 \mathrm{G} / 1$ i podwyższoną aktywność dehydrogenazy mleczanowej (LDH, lactate dehydrogenase $)$ - $674 \mathrm{j} . / 1$. Pozostałe parametry biochemiczne nie przekraczały normy. Oceniono mielogram, stwierdzając w bezgrudkowych, ubogokomórkowych preparatach obecność 80\% polimorficznych komórek limfoidalnych o nieregularnych okrągławych jądrach z luźniejszą lub bardziej skondensowaną chromatyną, małą ilością 


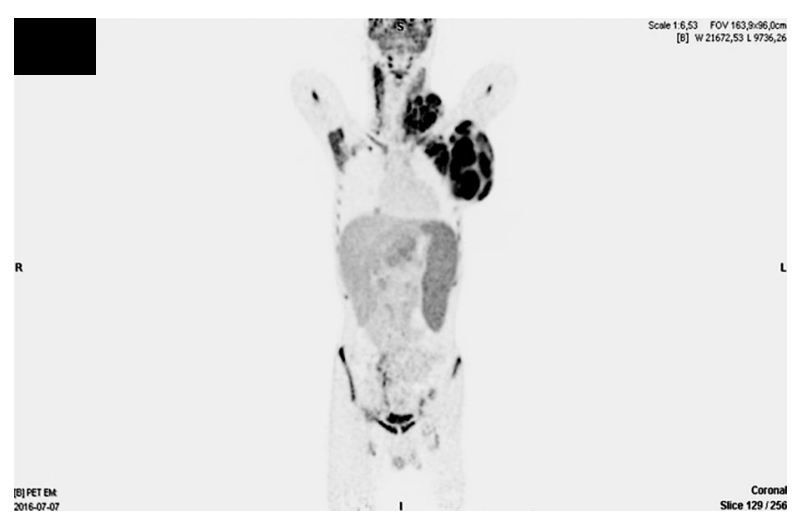

Rycina 2. Obraz pozytonowej tomografii emisyjnej/tomografii komputerowej w momencie rozpoznania choroby

Figure 2. Positron emission tomography/computed tomography image at diagnosis

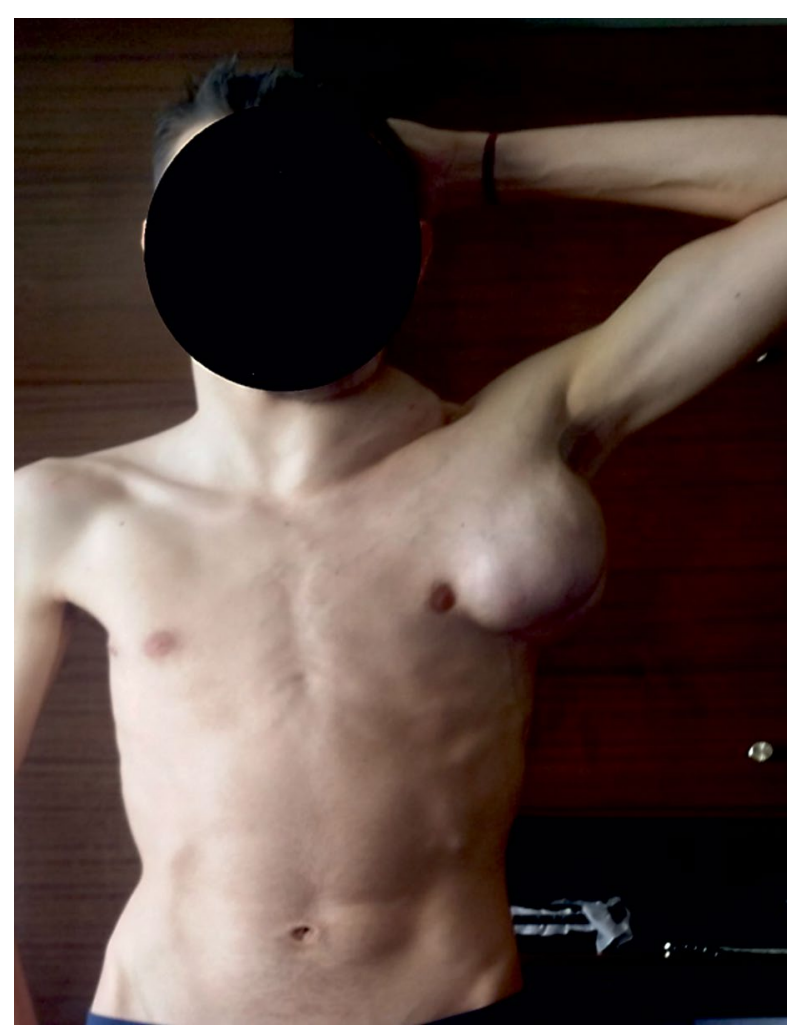

Rycina 3. Pakiety powiększonych węzłów chłonnych szyjnych i lewych pachowych

Figure 3. Packages of enlarged left cervical and axillary lymph nodes

zasadochłonnej cytoplazmy oraz pojedynczymi ziarnistościami kwasochłonnymi (ryc. 4). Powtórzono cytometryczne badanie szpiku, w którym opisano 73\% komórek blastycznych o nieco innym rozkładzie ekspresji antygenów: CD45(+), CD34(+),

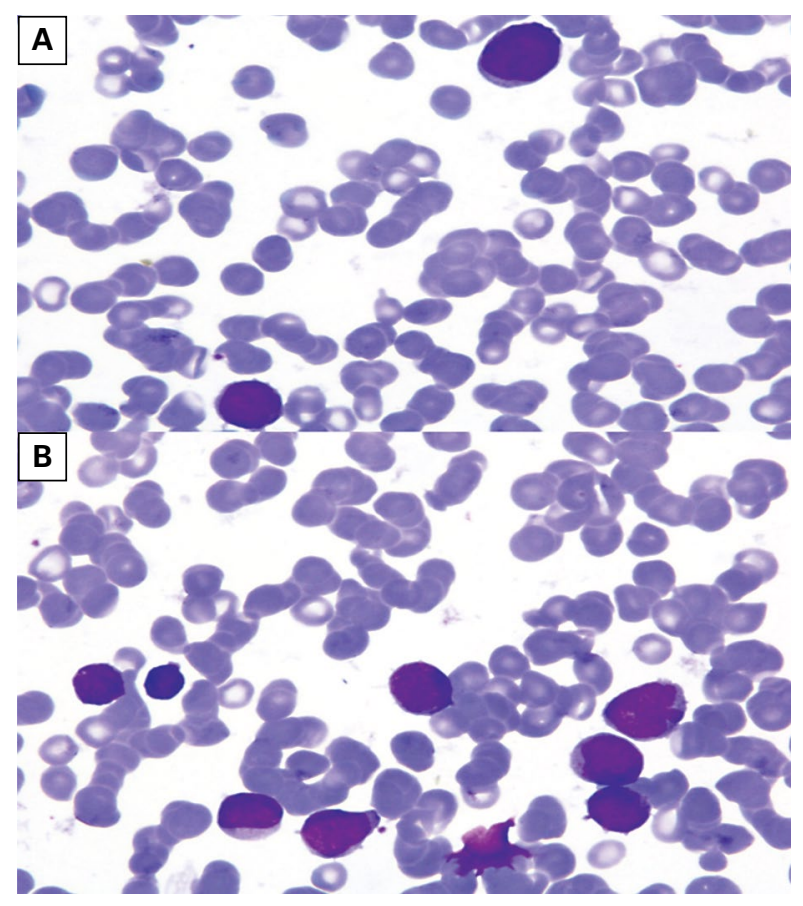

Rycina 4A, B. Komórki blastyczne w rozmazie szpiku (barwienie metodą Maya-Grünwalda-Giemsy, powiększenie $\times 100$ )

Figure 4A, B. Blast cells in bone marrow smear (MayGrünwald-Giemsa staining, $\times 100$ )

cytMPO(-), CD19(+) 10\%, cytCD79a(+) 14\%, CD7(+) 89\%, cyt CD3(-), CD3(-), CD13(-), CD11b $(+)^{\operatorname{dim}} 14 \%$, CD117 (+) 63\%, HLA-DR $(+)$, CD33(+) ${ }^{\operatorname{dim}} 10 \%, \mathrm{CD} 64(-), \operatorname{Cd} 14(-), \mathrm{CD} 65(-)$, CD10(-), CD16(-), CD4(+) $)^{\operatorname{dim}} 17 \%$, CD56(-), CD71(+) $\operatorname{dim} 77 \%$, CD38(+), CD99(-), TdT(-), CD1a(-), ale wciąż nie pozwalał on na zakwalifikowanie blastów do linii mielo- lub limfoidalnej. Diagnostykę uzupełniono o badania molekularne, w wyniku których nie znaleziono żadnej typowej dla ostrych rozrostów nowotworowych szpiku aberracji, tj.: duplikacja FLT3-ITD(-), mutacja NPM1(-), translokacja AML1-ETO(-), translokacja $M L L$ $-A F 4(-)$. W badaniu cytogenetycznym stwierdzono kariotyp męski 47XY, +11[19]/46XY[1]; w 19 na 20 metafaz opisano obecność trisomii chromosomu 11 występującej w rozrostach $z$ linii mieloidalnej i związanej ze złym rokowaniem.

Nie stwierdzono rearanżacji $B C R / A B L 1, M L L$, $I G H(14 \mathrm{q} 32)$ ani genów kodujących receptory limfocytów T: TLX3 (5q35), TCRB (7q34) TLX1 (10q24.31), TCRAD (14q11.2), TCL1 (14q32.13). 12 lipca 2016 roku rozpoczęto leczenie indukujące według protokołu PALG ALL6, które chory dobrze tolerował. 6 września 2016 roku oceniono efekt 
chemioterapii indukującej. W badaniu przedmiotowym stwierdzono znaczne, o około $75 \%$, zmniejszenie wymiarów zmian guzowatych. W badaniu immunofenotypowym szpiku $72,5 \%$ stanowiły komórki linii mieloidalnej zróżnicowane w stopniu dojrzałości, o fenotypie CD45(+), CD34(+) 1\%, CD117(+) $2 \%$, HLA-DR $(+)^{\operatorname{dim}} 10 \%$, CD33(+), cytMPO(+), CD13(+), Cd11b(+) 84\%, CD15(+), CD14(-), CD10(+) 39\%, CD16(+) 72\%, CD64(+), CD36(-), CD4(+) dim 16\%, CD56(-), CD71(+), CD7(-), CD19(-), cytCD3(-), CD3(-), cyt79a(-). Nie wykazano obecności komórek fenotypowo odpowiadających komórkom białaczkowym. Na podstawie tych badań, ze względu na resztkowe zmiany guzowate, rozpoznano częściową remisję choroby. Jednocześnie w badaniach laboratoryjnych stwierdzono głęboką anemię, ze stężeniem $\mathrm{Hb}$ $3,0 \mathrm{~g} / \mathrm{dl}$, miernie podwyższone stężenia bilirubiny całkowitej $(1,34 \mathrm{mg} / \mathrm{dl})$ i bezpośredniej $(0,3 \mathrm{mg} /$ /dl) oraz bardzo wysoką aktywność LDH - 2964 j./I. Rozpoznano anemię hemolityczną i wykonano identyfikację przeciwcial; na krwinkach i w surowicy wykryto obecność immunoglobulin klasy IgG niespełniających kryteriów autoprzeciwciał oraz składowej C3d dopełniacza. Wykryto także alloprzeciwciała odpornościowe o swoistości anty-E $z$ układu Rh oraz anty-K z układu Kell. Wynik bezpośredniego testu antyglobulinowego (BTA) był dodatni. Włączono steroidoterapię (metylprednizolon $125 \mathrm{mg}$ dożylnie), szybko uzyskując zahamowanie hemolizy. Po ustabilizowaniu stanu pacjenta, biorąc pod uwage fakt, $\dot{z}$ e w badaniu immunofenotypowym nie stwierdzono obecności blastów, mimo resztkowych zmian guzowatych rozpoczęto leczenie konsolidujące według protokołu PALG ALL6. Dalsze leczenie pacjenta przebiegało bez powikłań. W listopadzie 2016 roku chory był konsultowany w klinice transplantacji szpiku i onkohematologii i zakwalifikowano go do leczenia allo-HSCT od dawcy niespokrewnionego (URD-allo-HSCT, unrelated donor allo-HSCT), ponieważ chory nie ma rodzeństwa. W kwietniu 2017 roku, po zakończeniu trzeciego leczenia konsolidującego, wykonano kontrolne badanie PET/CT, w którym opisano całkowitą remisję metaboliczną choroby podstawowej (ryc. 5). W badaniu przedmiotowym również stwierdzono całkowite ustąpienie limfadenopatii (ryc. 6). W szpiku utrzymywała się całkowita remisja potwierdzona w badaniu cytometrii przepływowej. 28 kwietnia 2017 roku rozpoczęto leczenie podtrzymujące zgodnie $z$ protokołem ALL PALG6, które chory kontynuuje. Mimo znalezienia optymalnego dawcy niespokrewnionego chory nie zdecydował się na URD-HSCT.

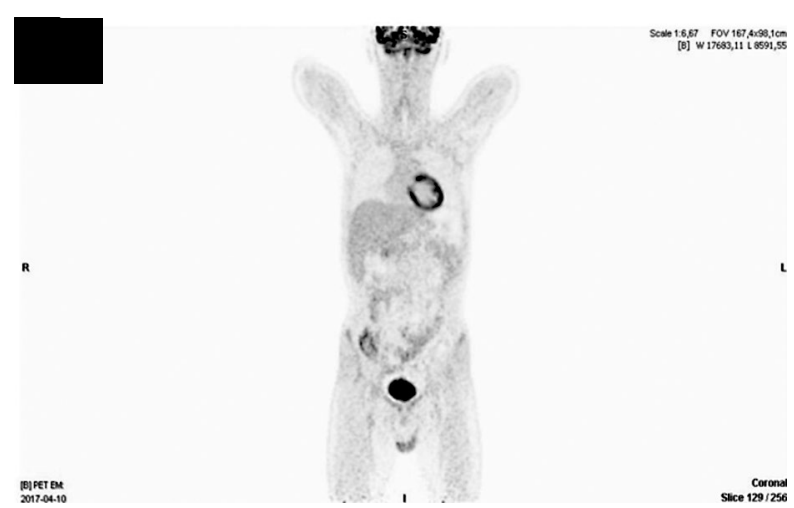

Rycina 5. Obraz całkowitej remisji metabolicznej w badaniu pozytonowej tomografii emisyjnej/tomografii komputerowej po zakończeniu leczenia

Figure 5. Image of total metabolic remission in positron emission tomography/computed tomography after treatment

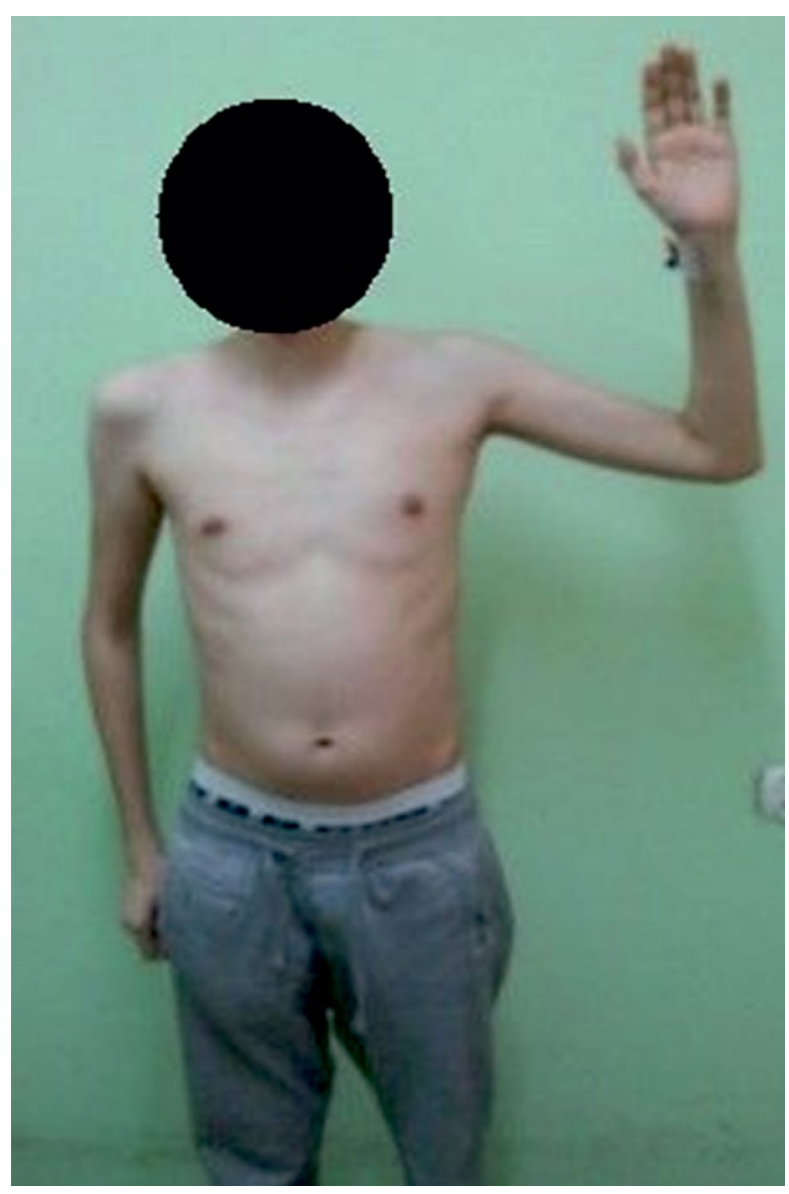

Rycina 6. Remisja zmian węzłowych w lewym nadobojczu i dole pachowym

Figure 6. Remission of left supraclavicular and axillary nodal changes 
Tabela 1. Kryteria klasyfikacji ostrej białaczki bifenotypowej według European Group for Immunological Classification of Leukemia (EGIL); wymagane ponad 2 punkty dla co najmniej dwóch linii komórkowych: limfocytów B, T lub mieloidalnej (źródło $[1,7])$

Table 1. European Group for Immunological Classification of Leukemia (EGIL) scoring system for biphenotypic acute leukemia; score greater than 2 is required for at least 2 lineages: B, T lineage or myeloid (source [1, 7])

\begin{tabular}{|l|c|c|c|}
\hline Punkty & Linia limfocytu B & Linia limfocytu T & Linia mieloidalna \\
\hline \multirow{3}{*}{2} & CD79a & CD3(cyt/m) & lizozym \\
\cline { 2 - 4 } & cytlgM & TCR $\alpha / \beta$ & CD13 \\
\cline { 2 - 4 } & cytCD22 & TCR $\gamma / \delta$ & CD33 \\
\hline \multirow{3}{*}{1} & & & CDw65 \\
\cline { 2 - 4 } & CD19 & CD2 & CD117 \\
\cline { 2 - 4 } & CD10 & CD5 & CD14 \\
\hline 0,5 & CD20 & CD8 & CD15 \\
\cline { 2 - 4 } & TdT & CD10 & CD64 \\
\cline { 2 - 4 } & CD24 & CD7 & \\
\hline
\end{tabular}

\section{Dyskusja}

Pacjenta $z$ rozpoznaną ostrą białaczką $(>20 \%$ blastów w szpiku lub mniej w przypadku obecności pewnych translokacji chromosomowych i lokalizacji pozaszpikowych) ogólnie można zaklasyfikować do leczenia jako chorego na ostrą białaczkę szpikową (AML, acute myeloid leukemia) lub ostrą białaczkę limfoblastyczną (ALL, acute lymphoblastic leukemia). Jednak w rzadkich przypadkach (2-3\% ostrych białaczek) niedojrzałe komórki wykazują cechy cytochemiczne i/lub immunofenotypowe obu linii jednocześnie (białaczki bifenotypowe) albo wspólistnieją dwie populacje blastów, każda $z$ innej linii (białaczki dwuliniowe) [1]. Możliwa jest również sytuacja, w której na powierzchni komórek w ogóle brakuje antygenów specyficznych liniowo (białaczki niezróżnicowane), a blasty wykazują głównie ekspresję CD34, HLA-DR lub CD38.

Istnieją dwie główne hipotezy tłumaczące występowanie mieszanych fenotypów. Według pierwszej ('lineage promiscuity', czyli „rozwiązłość liniowa”), krwiotwórcze komórki progenitorowe mają potencjał wieloliniowy, który zostaje zachowany, jeżeli na tym etapie zachodzi transformacja białaczkowa. Zgodnie $z$ hipotezą alternatywną ('lineage infidelity', czyli „niewierność liniowa”) zakłada się wywołane onkogenetycznie błędne programowanie komórki, co powoduje wieloliniową ekspresję antygenów blastów [2, 3]. Znajdują one potwierdzenie w badaniach, w których wykazano, że obecność genu fuzyjnego $M L L-E N L$ lub ostrej białaczki szpikowej $R U N X 1 / R U N X 1 T 1$-dodatniej może indukować zmianę przypisanych do linii T progenitorów do rozwoju w AML (,niewierność liniowa") [4-6]. W celu uproszczenia definicji i diagnostyki tych chorób w 1995 roku Europejska Komisja do Spraw Charakterystyki Immunologicznej Ostrych Białaczek (EGIL, European Group for the Immunological Characterization of Leukemias) stworzyła system punktowy, na podstawie którego białaczkę $z$ koekspresją antygenów limfo- i mieloidalnych można uznać za dwufenotypową (tab. 1) $[1,7]$. W 2001 roku Światowa Organizacja Zdrowia (WHO, World Health Organization) zaadaptowała klasyfikację zaproponowaną przez EGIL, modyfikując ją w rewizji Klasyfikacji Nowotworów Układu Krwiotwórczego i Chłonnego z 2008 roku do kształtu, w jakim obowiązuje obecnie (tab. 2) [8-10]. W klasyfikacji WHO wprowadzono podział białaczek o nieustalonej linii pochodzenia (acute leukemias of ambiguous lineage) na ostre białaczki niezróżnicowane (AUL, acute undifferentiated leukemia) oraz ostre białaczki o mieszanym fenotypie (MPAL, mixed-phenotype acute leukemia). Te przypadki można dalej klasyfikować jako T-mieloidalne lub B-mieloidalne zgodnie $z$ ekspresją ściśle określonych antygenów. W klasyfikacji MPAL osobne podgrupy stanowią białaczki $z$ translokacją $\mathrm{t}(9,22)$, rearanżacją $M L L$ oraz białaczki wtórne do chemioterapii i zespołów mielodysplastycznych (MDS, myelodysplastic syndromes), a także białaczki z mutacjami FGFR1 i przewlekła białaczka szpikowa (CML, chronic myelogenous leukemia) w fazie 
Tabela 2. Kryteria rozpoznania białaczki o mieszanym fenotypie (MPAL). Klasyfikacja nowotworów układu krwiotwórczego i chłonnego Światowej Organizacji Zdrowia (WHO) 2008/2016 (na podstawie [8-10])

Table 2. Criteria for the diagnosis of mixed phenotype leukemia (MPAL). World Health Organization (WHO) $2008 / 2016$ classification of myeloid neoplasms and acute leukemia (according to [8-10])

\begin{tabular}{|c|}
\hline Linia mieloidalna \\
\hline $\begin{array}{l}\text { Dodatnia mieloperoksydaza (w badaniach cytofluoryme- } \\
\text { trycznym, immunohistochemicznym albo cytochemicznym) } \\
\text { lub } \\
\text { cechy różnicowania w kierunku monocytu ( } \geq 2 \text { z nastę- } \\
\text { pujących: niespecyficzna esteraza, CD11c, CD14, CD64, } \\
\text { lizozym) }\end{array}$ \\
\hline Linia limfocytu T \\
\hline $\begin{array}{l}\text { Cytoplazmatyczne CD3 (w badaniu cytofluorymetrycznym } \\
\text { z przeciwciałami do łańcucha epsilon CD3; badania } \\
\text { immunohistochemiczne z przeciwciałami poliklonalnymi } \\
\text { anty-CD3 mogą wykrywać łańcuchy zeta, niespecyficzne } \\
\text { dla komórek T) } \\
\text { lub } \\
\text { powierzchniowe CD3 (rzadko w MPAL) }\end{array}$ \\
\hline Linia limfocytu B (wymagane kilka antygenów) \\
\hline $\begin{array}{l}\text { Silna ekspresja CD19 z } \geq 1 \text { silną ekspresją: CD79a, } \\
\text { cCD22, CD10 } \\
\text { lub } \\
\text { słaba eksresja CD19 z } \geq 2 \text { silnymi ekspresjami: CD79a, } \\
\text { cCD22, CD10 }\end{array}$ \\
\hline
\end{tabular}

kryzy blastycznej. W wydanej w 2016 roku rewizji do klasyfikacji nowotworów układów krwiotwórczego i chłonnego WHO nie wprowadzono istotnych zmian w systematyce tej grupy chorób. W 2009 roku, na podstawie profilowania ekspresji genów (GEP, gene expression profiling), wśród ostrych białaczek limfoblastycznych T-komórkowych zidentyfikowano podgrupę $z$ wczesnych prekursorowych komórek T (ETP-ALL, early T-cell precursor acute lymphoblastic leukemia). Obecnie definiuje się ją na podstawie fenotypu charakteryzującego się ekspresją CD7 i brakiem powierzchniowych antygenów linii T (CD1a, CD8) brakiem lub słabą ekspresją CD5 z towarzyszeniem aberrantnych antygenów mieloidalnych lub komórek pnia (np. CD117, CD34, HLA-DR, CD13, CD33, CD11b, i/lub CD65) [11]. Poza tym ETP-ALL jest związana z częstym występowaniem mutacji specyficznych dla nowotworów mieloidalnych, takich jak FLT3, NRAS/KRAS, DNMT3A, IDH1 i IDH2, natomiast rzadziej występują mutacje typowe dla ALL, na przykład aktywujące mutacje NOTCH1 [12-14]. Ze względu na coraz liczniejsze doniesienia w literaturze dotyczące zmian genetycznych, przebiegu i rokowania ETP-ALL włączono ją do klasyfikacji ostrych białaczek według WHO w 2016 roku.

Obecnie nie jest jasne, czy chorych na ostrą białaczkę o mieszanym fenotypie należy leczyć według schematów przeznaczonych dla AML, ALL czy może ich kombinacją $[1,15,16]$. Oprócz faktu, że jest to mała (2-3\% ostrych białaczek) heterogenna grupa chorób, to analizę danych komplikuje istnienie dwóch kompetytywnych systemów klasyfikacyjnych EGIL i WHO. System WHO jest bardziej zamknięty (z powodu mniejszej liczby stosowanych w klasyfikacji antygenów), co może skutkować zaniżoną rozpoznawalnością przypadków MPAL. Weinberg i Arber w retrospektywnej analizie obejmującej 7627 pacjentów pediatrycznych oraz dorosłych $z$ ostrą białaczką rozpoznali $2,8 \%$ białaczek bifenotypowych i $1,6 \%$ białaczek o mieszanym fenotypie przy użyciu, odpowiednio, systemów EGIL i WHO 2008 [17]. Podobnie wśród badanych 517 holenderskich pacjentów pediatrycznych oraz dorosłych $z$ ostrą białaczką $5,8 \%$ byłoby sklasyfikowanych jako chorzy na białaczkę bifenotypową według kryteriów EGIL, a tylko $1,5 \%$ spełniłoby kryteria białaczki o mieszanym fenotypie zgodnie $z$ klasyfikacją WHO 2008 [15]. Pokazuje to, że zależnie od wybranego systemu inaczej zostanie sklasyfikowana ta sama grupa chorych. W opublikowanej w 2016 roku w „Blood Research” pracy Pomerantz i wsp. [7] wskazali na znacznie krótsze mediany przeżycia wolnego od choroby (DFS, disease-free survival) i przeżycia całkowitego (OS, overall survival) wśród pacjentów $z$ ostrą białaczką o mieszanym fenotypie w porównaniu $z$ chorymi na inne postacie ostrych białaczek: DFS 6 miesięcy i OS 8 miesięcy w przypadku MPAL, następnie odpowiednio DFS 9 miesięcy i OS 13 miesięcy u pacjentów z ALL oraz DFS 9 miesięcy i OS 18 miesięcy u chorych na AML. Równocześnie stwierdzono dłuższe OS u pacjentów leczonych chemioterapią typu ALL w porównaniu ze schematami typu AML [7, 18]. Tych obserwacji, choć zgodnych z wcześniejszymi doniesieniami, nie uznano za jednoznaczne wskazanie, aby pacjentów z MPAL leczyć według protokołów zalecanych dla ALL [18-21]. Rekomenduje się konsultacje $z$ ośrodkiem doświadczonym w zakresie leczenia tych szczególnych jednostek. Specyficzną grupę chorych na MPAL stanowią pacjenci $z$ obecnością chromosomu Filadelfia $(\mathrm{Ph}$, Philadelphia) - MPAL-Ph(+). Ta postać choroby jest zazwyczaj kombinacją markerów B-limfocytarnych i mieloidalnych, i stanowi około $25 \%$ wszystkich MPAL [22]. Choć zasadniczo autorzy wszystkich opracowań, w których opisano tę jednostkę, 
wskazują na niekorzystne rokowanie wywołane przez obecność $\mathrm{Ph}(+)$, w erze inhibitorów kinaz tyrozynowych sytuacja może się zmieniać $[18,23]$.

\section{Podsumowanie}

Jest oczywiste, $\dot{z}$ e jednostkowy przypadek korzystnego efektu leczenia białaczki o nieustalonym fenotypie, postaci białaczki obciążonej wyjątkowo złym rokowaniem, nie może być podstawą do wyciągania daleko idących wniosków terapeutycznych. Dlatego należy $z$ dawać sobie sprawę $z$ tego, że możliwość skuteczniejszego leczenia chorych na białaczki $z$ tej podgrupy musi być ściśle rozpatrywana w ramach większej ilości wysokiej jakości danych oraz przeprowadzonych badań klinicznych. Kluczowe wydaje się również ujednolicenie kryteriów rozpoznawania MPAL/AUL, zwłaszcza biorąc pod uwagę relatywną rzadkość ich występowania. Być może badanie immunofenotypowe, będące podstawą diagnostyki ostrych białaczek, jest nieadekwatne w przypadku białaczek limfomieloblastycznych i do zrozumienia ich natury konieczne będą dalszy rozwój i analiza wyników badań genetycznych.

\section{Piśmiennictwo}

1. Wolach O, Stone RM. How I treat mixed-phenotype acute leukemia. Blood. 2015; 125(16): 2477-2485, doi: 10.1182/ blood-2014-10-551465, indexed in Pubmed: 25605373.

2. Greaves MF, Chan LC, Furley AJ, et al. Lineage promiscuity in hemopoietic differentiation and leukemia. Blood. 1986; 67(1): 1-11, indexed in Pubmed: 3079640.

3. Smith LJ, Curtis JE, Messner HA, et al. Lineage infidelity in acute leukemia. Blood. 1983; 61(6): 1138-1145, indexed in Pubmed: 6404327.

4. Nishiuchi T, Ohnishi H, Kamada R, et al. Acute leukemia of ambiguous lineage, biphenotype, without CD34, TdT or TCRrearrangement. Intern Med. 2009; 48(16): 1437-1441, indexed in Pubmed: 19687594.

5. Deshpande AJ, Buske C. Lymphoid progenitors as candidate cancer stem cells in AML: new perspectives. Cell Cycle. 2007; 6(5): 543-545, doi: 10.4161/cc.6.5.3968, indexed in Pubmed: 17329976.

6. Yan M, Kanbe E, Peterson LF, et al. A previously unidentified alternatively spliced isoform of $t(8 ; 21)$ transcript promotes leukemogenesis. Nat Med. 2006; 12(8): 945-949, doi: 10.1038/nm1443, indexed in Pubmed: 16892037.

7. Pomerantz A, Rodriguez-Rodriguez S, Demichelis-Gomez R, et al. Mixed-phenotype acute leukemia: suboptimal treatment when the 2008/2016 WHO classification is used. Blood Res. 2016; 51(4): 233-241, doi: 10.5045/br.2016.51.4.233, indexed in Pubmed: 28090485 .

8. Béné MC. Biphenotypic, bilineal, ambiguous or mixed lineage: strange leukemias! Haematologica. 2009; 94(7): 891-893, doi: 10.3324/haematol.2009.007799, indexed in Pubmed: 19570749.
9. Vardiman JW, Thiele J, Arber DA, et al. The 2008 revision of the World Health Organization (WHO) classification of myeloid neoplasms and acute leukemia: rationale and important changes. Blood. 2009; 114(5): 937-951, doi: 10.1182/blood-2009-03-209262, indexed in Pubmed: 19357394.

10. Zhao XF, Gojo I, York T, et al. Diagnosis of biphenotypic acute leukemia: a paradigmatic approach. Int J Clin Exp Pathol. 2009; 3(1): 75-86, indexed in Pubmed: 19918331.

11. Coustan-Smith E, Mullighan CG, Oncui M. Early T-cell precursor leukemia: a subtype of very high-risk acutelymphoblastic leukemia identified in two independent cohorts. Lancet Oncol. 2009; 10(2): 147-156.

12. Neumann M, Heesch S, Schlee C, et al. Whole-exome sequencing in adult ETP-ALL reveals a high rate of DNMT3A mutations. Blood. 2013; 121(23): 4749-4752, doi: 10.1182/ blood-2012-11-465138, indexed in Pubmed: 23603912.

13. Neumann M, Coskun E, Fransecky L, et al. FLT3 mutations in early T-cell precursor ALL characterize a stem cell like leukemia and imply the clinical use of tyrosine kinase inhibitors. PLoS One. 2013; 8(1): e53190, doi: 10.1371/journal.pone.0053190, indexed in Pubmed: 23359050.

14. Zhang J, Ding Li, Holmfeldt L, et al. The genetic basis of early T-cell precursor acute lymphoblastic leukaemia. Nature. 2012; 481(7380): 157-163, doi: 10.1038/nature10725, indexed in Pubmed: 22237106.

15. van den Ancker W, Terwijn M, Westers TM, et al. Acute leukemias of ambiguous lineage: diagnostic consequences of the WHO2008 classification. Leukemia. 2010; 24(7): 1392-1396, doi: 10.1038/ leu.2010.119, indexed in Pubmed: 20485373.

16. Munker R, Brazauskas R, Wang HL, et al. Center for International Blood and Marrow Transplant Research. Allogeneic hematopoietic cell transplantation for patients with mixed phenotype acute leukemia. Biol Blood Marrow Transplant. 2016; 22(6): 1024-1029, doi: 10.1016/j.bbmt.2016.02.013, indexed in Pubmed: 26903380.

17. Weinberg OK, Arber DA. Mixed-phenotype acute leukemia: historical overview and a new definition. Leukemia. 2010; 24(11): 1844 -1851, doi: 10.1038/leu.2010.202, indexed in Pubmed: 20844566.

18. Matutes E, Pickl WF, Van't Veer M, et al. Mixed-phenotype acute leukemia: clinical and laboratory features and outcome in 100 patients defined according to the WHO 2008 classification. Blood. 2011; 117(11): 3163-3171, doi: 10.1182/blood-2010-10-314682, indexed in Pubmed: 21228332.

19. Heesch S, Neumann M, Schwartz S, et al. Acute leukemias of ambiguous lineage in adults: molecular and clinical characterization. Ann Hematol. 2013; 92(6): 747-758, doi: 10.1007/s00277-0131694-4, indexed in Pubmed: 23412561.

20. Zhang Y, Wu D, Sun A, et al. Clinical characteristics, biological profile, and outcome of biphenotypic acute leukemia: a case series. Acta Haematol. 2011; 125(4): 210-218, doi: 10.1159/000322594, indexed in Pubmed: 21266800.

21. Liu QF, Fan ZP, Wu MQ, et al. Allo-HSCT for acute leukemia of ambiguous lineage in adults: the comparison between standard conditioning and intensified conditioning regimens. Ann Hematol. 2013; 92(5): 679-687, doi: 10.1007/s00277-012-1662-4, indexed in Pubmed: 23274355.

22. Manola KN. Cytogenetic abnormalities in acute leukaemia of ambiguous lineage: an overview. Br J Haematol. 2013; 163(1): 24-39, doi: 10.1111/bjh.12484, indexed in Pubmed: 23888868.

23. Killick S, Matutes E, Powles RL, et al. Outcome of biphenotypic acute leukemia. Haematologica. 1999; 84(8): 699-706, indexed in Pubmed: 10457405. 